\title{
Muscarinic receptor subtypes and signalling involved in the attenuation of isoprenaline-induced rat urinary bladder relaxation
}

\author{
Lambertus P. W. Witte • Noach de Haas • \\ Mathai Mammen • Eric L. Stangeland • Tod Steinfeld • \\ Jayashree Aiyar • Martin C. Michel
}

Received: 25 April 2011 / Accepted: 26 August 2011 / Published online: 24 September 2011

(C) The Author(s) 2011. This article is published with open access at Springerlink.com

\begin{abstract}
Adrenoceptors are important mediators of smooth muscle relaxation in the urinary bladder, but the concomitant presence of a muscarinic agonist, e.g., carbachol, can attenuate relaxation responses by reducing potency and/or efficacy of $\beta$-adrenoceptor agonists such as isoprenaline. Therefore, the present study was designed to explore the subtypes and signalling pathways of muscarinic receptors involved in the attenuation of isoprenaline-induced isolated rat detrusor preparations using novel subtypeselective receptor ligands. In radioligand binding studies, we characterized BZI to be a $\mathrm{M}_{3}$-sparing muscarinic agonist, providing selective $\mathrm{M}_{2}$ stimulation in rat bladder, and THRX-182087 as a highly $\mathrm{M}_{2}$-selective antagonist. The use of BZI and of THRX-182087 in the presence of carbachol enabled experimental conditions with a selective stimulation of only $\mathrm{M}_{2}$ or $\mathrm{M}_{3}$ receptors, respectively. Confirming previous findings, carbachol attenuated isoprenaline-induced detrusor relaxation. $\mathrm{M}_{2}$-selective stimulation partly mimicked this attenuation, indicating that both
\end{abstract}

L. P. W. Witte $\cdot$ N. de Haas $\cdot$ M. C. Michel

Depts. of Pharmacology and Pharmacotherapy and of Urology,

Academic Medical Center,

Amsterdam, The Netherlands

M. Mammen · E. L. Stangeland - T. Steinfeld · J. Aiyar

Theravance Inc.,

South San Franciso, CA, USA

Present Address:

M. C. Michel $(\bowtie)$

Clinical Development and Medical Affairs,

Boehringer Ingelheim Pharma GmbH and Co. KG,

Binger Str. 173,

55216 Ingelheim am Rhein, Germany

e-mail: martincmichel@yahoo.de
$M_{2}$ and $M_{3}$ receptors are involved. During $M_{3}$-selective stimulation, the attenuation of isoprenaline responses was reduced by the phospholipase $\mathrm{C}$ inhibitor $\mathrm{U} 73,122$ but not by the protein kinase $\mathrm{C}$ inhibitor chelerythrine. We conclude that both $\mathrm{M}_{2}$ and $\mathrm{M}_{3}$ receptors contribute to attenuation of $\beta$ adrenoceptor-mediated relaxation of rat urinary bladder; the signal transduction pathway involved in the $\mathrm{M}_{3}$ component of this attenuation differs from that mediating direct contractile effects of $\mathrm{M}_{3}$ receptors.

Keywords $M_{2}$ muscarinic receptor $\cdot M_{3}$ muscarinic receptor $\cdot$ THRX-182087 · $\beta$-Adrenoceptor - Relaxation . Urinary bladder

\section{Introduction}

Muscarinic receptors are the main mediator of physiological contraction of the urinary bladder. While $\mathrm{M}_{2}$ and $\mathrm{M}_{3}$ subtypes exist in an about 4:1 ratio in the bladder of humans and many other mammals, direct contraction responses to exogenous agonists or endogenous agonist as released by field stimulation are mediated predominantly if not exclusively by the minor fraction of $\mathrm{M}_{3}$ receptors (Hegde 2006). While it has been questioned on theoretical grounds that subtype-selective antagonists are sufficient to support this conclusion (Ehlert 2003), it should be noted that it is consistent with findings from $\mathrm{M}_{2}$ and $\mathrm{M}_{3}$ receptor knockout mice (Matsui et al. 2002). $\mathrm{M}_{3}$ receptors, including those in the urinary bladder, couple to phospholipase C (PLC) stimulation, but the direct contractile effect via $\mathrm{M}_{3}$ receptors occurs largely independent of PLC in the bladder (Frazier et al. 2008). On the other hand, bladder smooth muscle relaxation is mediated by $\beta$-adrenoceptors, in humans and many species mostly their $\beta_{3}$ subtype (Michel 
and Vrydag 2006). While $\beta$-adrenoceptors, including those in the bladder, couple to stimulation of an adenylyl cyclase, bladder relaxation by $\beta$-adrenergic agonists occurs largely independent of adenylyl cyclase stimulation (Frazier et al. 2008). Thus, bladder smooth muscle tone is under a dual control of $\mathrm{M}_{3}$ muscarinic receptors and $\beta$-adrenoceptors. This is similar to smooth muscle tone regulation in many other tissues, e.g., the airways, except relaxation responses in most cases outside the bladder are mediated by the $\beta_{2}$ subtype (Michel and Parra 2008).

The physiological control of bladder function involves activation of $\beta$-adrenoceptors by neuronally released noradrenaline during the storage phase of the micturition cycle, whereas neuronally released acetylcholine acting on $\mathrm{M}_{3}$ receptors mediates detrusor contraction during the voiding phase (Andersson et al. 2009). However, under pathophysiological conditions nonneuronal acetylcholine release from the urothelium may also play a role and can be present not only during the voiding but also the storage phase (Andersson 2011). The concomitant exposure of the detrusor to noradrenaline and acetylcholine during the storage phase may have important implications for bladder smooth muscle function. Thus, it has been shown that the potency and efficacy of a muscarinic agonist to elicit detrusor contraction is attenuated in the presence of a $\beta$-adrenoceptor agonist (Yamanishi et al. 2002). Perhaps even more important, muscarinic agonists can also attenuate the relaxing effects of $\beta$-adrenoceptor stimulation in the bladder (Ehlert et al. 2007; Longhurst and Levendusky 1999; Michel and Sand 2009), airways (Matsui et al. 2003; Naline et al. 2007; Sarria et al. 2002), and ileum (Matsui et al. 2003). Such attenuation has been shown across multiple species, i.e., rat (Longhurst and Levendusky 1999; Michel and Sand 2009), mouse (Ehlert et al. 2007; Matsui et al. 2003), and humans (Naline et al. 2007; Sarria et al. 2002), indicating that it is a general principle in the regulation of smooth muscle tone upon concomitant exposure to muscarinic and $\beta$-adrenoceptor agonists. While all studies agree on the existence of attenuation of $\beta$-adrenoceptor-mediated relaxation by muscarinic agonists, reduced potency and/or efficacy have been reported to underlie such attenuation. Of note, the degree of attenuation of $\beta$-adrenoceptor-mediated relaxation by muscarinic agonists exceeds that by other contractile stimuli in all cases where this has been studied, e.g., that by $\mathrm{KCl}$, bradykinin, or serotonin in the bladder (Michel and Sand 2009) or that of histamine in the airways (Naline et al. 2007; Roffel et al. 1995). At least in rat bladder, this differential degree of attenuation cannot be explained by a comparison between weak and strong contractile agonists, indicating that it may involve a specific property of muscarinic receptors rather than purely reflecting functional antagonism.

The interaction between muscarinic receptors and $\beta$ adrenoceptors may also shed light on the physiological role of the numerous $\mathrm{M}_{2}$ receptors in bladder and airways. Thus, $\mathrm{M}_{2}$ receptor knockout mice exhibited a mitigated attenuation of relaxation responses to isoprenaline (Ehlert et al. 2007; Matsui et al. 2003) and receptor-independent elevation of cellular cAMP content such by the adenylyl cyclase activator forskolin (Pak et al. 2010). As $\mathrm{M}_{2}$ receptors largely signal via pertussis toxin-sensitive $G$ proteins (Caulfield and Birdsall 1998), further support for a role of $\mathrm{M}_{2}$ receptors in the attenuation response comes from studies in which pertussis toxin treatment enhanced the relaxant effects of forskolin on oxotremorine-M-mediated contractions in the ileum and trachea (Ostrom and Ehlert 1998, 1999). In a similar vein, it has been reported that under conditions of preferential alkylation of $\mathrm{M}_{3}$ receptors, the ability of a muscarinic agonist to reverse isoprenaline-induced relaxation is largely maintained (Ehlert et al. 2005; Hegde et al. 1997). Facing a lack of highly subtype-selective muscarinic antagonists, such alkylation protocols have been employed by several investigators to achieve reasonable subtype selectivity. While this has been successful in some cases under very specific conditions (Griffin et al. 2009), other alkylation protocols have proven to be poorly selective (Braverman and Ruggieri 1999). Moreover, in some cases, $\mathrm{M}_{3}$ responses have also been pertussis toxin sensitive (Offermanns et al. 1994), making pertussis toxin an unreliable witness of $\mathrm{M}_{2}$ involvement. While the knockout mice circumvent selectivity problems, they are prone to other complications such as compensatory regulation of other receptors or signal transduction pathways.

Recently, an agonist with considerable selectivity for $\mathrm{M}_{2}$ over $\mathrm{M}_{3}$ receptors became available, but this compound exhibits a lower degree of selectivity, if any, over other subtypes; in the bladder, where muscarinic receptor subtypes other than $\mathrm{M}_{2}$ and $\mathrm{M}_{3}$ are largely absent, this compound produces selective $\mathrm{M}_{2}$ stimulation (Jasper et al. 2002; Schneider et al. 2005; Yamakawa et al. 2001a). Lacking a better term, we refer to this compound as " $\mathrm{M}_{3}$ sparing" in the present manuscript. Moreover, we have recently discovered an $\mathrm{M}_{2}$ receptor antagonist with unprecedented selectivity for this subtype, which we report here for the first time (Fig. 1). These two tools have enabled us to explore the role of $\mathrm{M}_{2}$ and $M_{3}$ receptors in the attenuation of isoprenaline-induced bladder relaxation. Moreover, we have used this approach to characterize the role of PLC and protein kinase C (PKC) activation in the attenuation response.

\section{Methods}

Radioligand binding experiments

Radioligand binding assays were conducted with $1 \mathrm{nM}\left[{ }^{3} \mathrm{H}\right]$ $\mathrm{N}$-methyl scopolamine (GE Healthcare, Piscataway, NJ, 
Fig. 1 Structures of THRX199874 (BZI) and THRX-182087

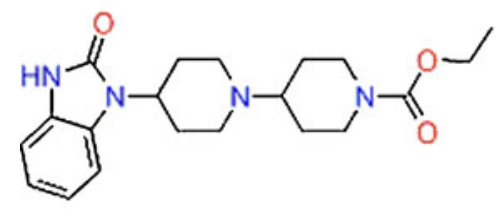

THRX-199874

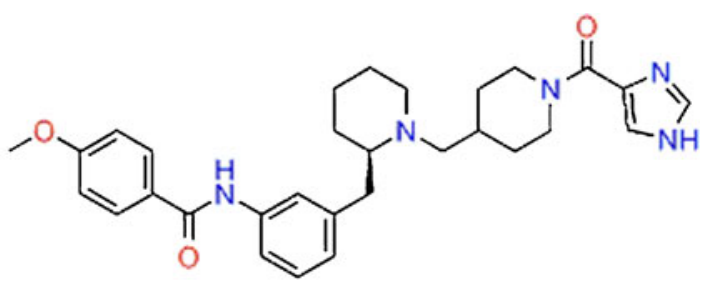

THRX-182087
USA) in a buffer consisting of $10 \mathrm{mM}$ HEPES, $100 \mathrm{mM}$ $\mathrm{NaCl}, 10 \mathrm{mM} \mathrm{MgCl}$, and $0.025 \%$ bovine serum albumin, $\mathrm{pH} 7.4$ at $37^{\circ} \mathrm{C}$. Nonspecific binding was defined in the presence of $10 \mu \mathrm{M}$ atropine. Membrane fractions from CHO-K1 cells expressing human recombinant $\mathrm{M}_{1}, \mathrm{M}_{2}, \mathrm{M}_{3}$, $\mathrm{M}_{4}$, or $\mathrm{M}_{5}$ muscarinic receptors were incubated with radioligand and unlabelled drugs for $1 \mathrm{~h}$ at $37^{\circ} \mathrm{C}$ in a volume of $100 \mu \mathrm{l}$. Receptor expression levels $\left(B_{\max }\right)$ measured by saturation binding were determined to be $2.7,2.5,2.4,2.0$, and $3.2 \mathrm{pmol} / \mathrm{mg}$ protein for human recombinant $\mathrm{M}_{1}, \mathrm{M}_{2}, \mathrm{M}_{3}, \mathrm{M}_{4}$, or $\mathrm{M}_{5}$ muscarinic receptors, respectively. After separation by vacuum filtration onto $\mathrm{GF} / \mathrm{B}$ filter plates presoaked with $0.3 \%$ polyethyleneimine, the quantity of membrane-bound radioligand was measured by scintillation counting.

Organ bath experiments

Tissue preparation Adult male Wistar rats weighing 300土 $22 \mathrm{~g}$ were purchased from Charles River (Maastricht, The Netherlands). Animals were anesthetized using pentobarbital $(75 \mathrm{mg} / \mathrm{kg}$, i.p.) and sacrificed by decapitation. The bladders were harvested, and adipose and soft connective tissues were removed. After removal of the dome and the trigonum, the middle parts of the cleaned bladders (weight of $96 \pm 15 \mathrm{mg}$ ) were cut transversally in four equal strips. The strips had a length of $19.9 \pm 3.6 \mathrm{~mm}$ and a weight of $9.5 \pm$ $2.7 \mathrm{mg}(n=76)$. All experimental procedures were in line with European Union guidelines for the use of laboratory animals and approved by the Animal Care Committee of Academisch Medisch Centrum.

Relaxation experiments Experiments were performed as previously described (Frazier et al. 2011) with minor modifications. Briefly, the bladder strips were mounted under a resting tension of $10 \mathrm{mN}$ in organ baths containing $7 \mathrm{ml}$ of Krebs-Henseleit buffer of the following composition: $118.5 \mathrm{mM} \mathrm{NaCl}, 4.7 \mathrm{mM} \mathrm{KCl}, 1.2 \mathrm{mM} \mathrm{MgSO}_{4}$, $0.025 \mathrm{mM} \mathrm{Na}_{4}$ EDTA, $2.5 \mathrm{mM} \mathrm{CaCl}$, $1.2 \mathrm{mM} \mathrm{KH}_{2} \mathrm{PO}_{4}$, $25 \mathrm{mM} \mathrm{NaHCO}_{3}$, and $5.6 \mathrm{mM}$ glucose at a temperature of $37^{\circ} \mathrm{C}$, yielding a total potassium concentration of $5.9 \mathrm{mM}$. The organ baths were continually gassed 95\% $\mathrm{O}_{2} / 5 \% \mathrm{CO}_{2}$ to maintain a $\mathrm{pH}$ of 7.4. The bladder strips were equilibrated for $120 \mathrm{~min}$, during which the buffer solution was refreshed every $15 \mathrm{~min}$ until a steady contractile state had been reached. Following the equilibration, the tissues were challenged with $50 \mathrm{mM} \mathrm{KCl}$ for $6 \mathrm{~min}$ (maintaining isoosmolarity by reducing $\mathrm{NaCl}$ concentration from 116.8 to $68.5 \mathrm{mM}$ ). After the first challenge, we equilibrated the strips again at passive tension of $10 \mathrm{mN}$ for $90 \mathrm{~min}$ and challenged the strips again with $50 \mathrm{mM} \mathrm{KCl}$ for $6 \mathrm{~min}$. After $60 \mathrm{~min}$ equilibration at $10 \mathrm{mN}$ after the second $\mathrm{KCl}$ challenge, we added vehicle or substance of interest. Strips with a $\mathrm{KCl}$ response of $<20 \mathrm{mN}$ were excluded. Carbachol was used at a concentration of $1 \mu \mathrm{M}$, BZI and THRX at $100 \mathrm{nM}$. The enzyme inhibitors U 73,122 (10 $\mu \mathrm{M})$ and chelerythrine $(1 \mu \mathrm{M})$ were added $5 \mathrm{~min}$ prior to the administration of THRX. Ten minutes later carbachol (1 $\mu \mathrm{M})$ was added, which was given an incubation time of 15 min to reach steady contractile stadium. Thereafter, cumulative concentration-response curves were generated for the $\beta$-adrenoceptor agonist isoprenaline. As isoprenaline-induced rat bladder relaxation can exhibit desensitization (Vrydag and Michel 2009), only one isoprenaline concentration-response curve was constructed per bladder strip; however, conditions being compared were always tested in parallel using strips from the same animal, and those paired comparisons were the basis of our statistical analysis (see below).

\section{Chemicals}

The $\mathrm{M}_{3}$-sparing agonist BZI [also known as THRX199874, 4-(2-oxo-2,3-dihydro-benzimidazol-1-yl)-1,4'-bipiperidinyl-1'-carboxylic acid ethyl ester] was synthesized at Theravance as described (Yamakawa et al. 2001b). The $\mathrm{M}_{2}$ selective antagonist THRX-182087 [N-(3-\{(R)-1-[1-(1Himidazole-4-carbonyl)-piperidin-4-ylmethyl]-piperidin-2ylmethyl \}-phenyl)-4-methoxy-benzamide] was synthesized in house as follows: Preparation of THRX-182087 was initiated from the condensation of 4-methoxyl benzoyl chloride and 3-bromo aniline. Metal halogen exchange with $n$-butyllithium in the presence of triethylchlorosilane and addition to (R)-2-formyl-1-Cbz-piperidine, followed by decarboxylation with palladium on carbon and potassium formate. Reductive alkylation with 4-formyl-1-Cbz-piperidine and $\mathrm{Cbz}$ removal with palladium on carbon, followed 
Table 1 Affinity estimates of BZI and THRX-182087 at human muscarinic receptor subtypes as determined in competition radioligand binding studies

\begin{tabular}{lcc}
\hline & BZI & THRX-182087 \\
\hline $\mathrm{M}_{1}$ & $7.27 \pm 0.04$ & $6.82 \pm 0.02$ \\
$\mathrm{M}_{2}$ & $8.59 \pm 0.05$ & $9.06 \pm 0.02$ \\
$\mathrm{M}_{3}$ & $<5$ & $6.61 \pm 0.02$ \\
$\mathrm{M}_{4}$ & $8.01 \pm 0.05$ & $7.34 \pm 0.02$ \\
$\mathrm{M}_{5}$ & $6.11 \pm 0.05$ & $5.46 \pm 0.02$ \\
\hline
\end{tabular}

Data are means $\pm \mathrm{SEM}$ of $19-27$ experiments and shown as $\mathrm{p} K_{\mathrm{I}}$ values

by acylation with $1 H$-imidazole-4-carbonyl chloride provided THRX-182087 (for detailed synthetic route see Stangeland et al., manuscript in preparation). U 73,122 [1(6-[([17ß]-3-methoxyestra-1,3,5[10]-trien-17-yl)-amino] hexyl)-1H-pyrrole-2,5-dione] was obtained from SigmaAldrich (Zwijndrecht, The Netherlands) and chelerythrine $\mathrm{HCl}$ from Calbiochem (via VWR, Amsterdam, The Netherlands).

\section{Data analysis}

Bound radioactivity in counts-per-minute data was normalized to percent specific binding and analyzed using a fourparameter logistic equation in Prism 3.0 (GraphPad Software, San Diego, CA, USA). Because Hill coefficients did not significantly differ from unity, $\mathrm{IC}_{50} \mathrm{~s}$ were determined with slopes fixed to 1 . Inhibition binding constants $\left(K_{\mathrm{I}}\right)$ for test compounds were calculated from the $\mathrm{IC}_{50}$ values using the Cheng and Prusoff correction (Cheng and Prusoff 1973) and reported as the mean negative logarithm of the inhibition binding constants $\left(\mathrm{p} K_{\mathrm{I}}\right) \pm \mathrm{SEM}$.
Nonlinear regression was used to fit sigmoidal curves to the isoprenaline concentration-response curves to determine agonist potency $\left(\mathrm{pEC}_{50}\right)$ and maximum effects $\left(E_{\max }\right)$ using Prism 5.0. The force of contraction immediately prior to addition of the first isoprenaline concentration within a given experiment was defined as $0 \%$ relaxation, and a force of contraction of $0 \mathrm{mN}$ was defined as $100 \%$ relaxation.

All data are expressed as mean \pm SEM of $n$ experiments. Statistical significance of inhibitor effects on the $E_{\max }$ or $\mathrm{pEC}_{50}$ of isoprenaline was assessed by paired two-tailed $t$ tests as compared to the indicated control condition, with treated and control conditions being measured in paired strips prepared from the same bladder. All statistical analyses were calculated using the Prism program, and a $p<0.05$ was considered statistically significant.

\section{Results}

The affinities of BZI and THRX-182087 for human recombinant $\mathrm{M}_{1}, \mathrm{M}_{2}, \mathrm{M}_{3}, \mathrm{M}_{4}$, and $\mathrm{M}_{5}$ muscarinic receptors as determined in competition radioligand binding experiments are shown in Table 1, most notably demonstrating a $>100$-fold selectivity for $\mathrm{M}_{2}$ over $\mathrm{M}_{3}$ receptors for both compounds.

Five series of functional experiments were performed. In the first series, we reinvestigated the role of muscarinic receptor stimulation vs. receptor-independent bladder contraction, induced by $\mathrm{KCl}$, for isoprenaline-induced relaxation. Carbachol and $\mathrm{KCl}$ caused a comparable starting tension (Table 2). The maximum relaxation by isoprenaline was significantly smaller in carbachol- than $\mathrm{KCl}$ precontracted strips, whereas the potency of isoprenaline
Table 2 Starting tension of relaxation experiments in the absence and presence of muscarinic agonists and antagonists and/or signal transduction inhibitors

Data are means \pm SEM of the indicated number of experiments and shown in millinewtons per milligram strip weight ${ }^{*} p<0.05$ vs. test condition $(\mathrm{KCl}$, carbachol, or passive tension) in a paired, two-tailed $t$ test
Series 1: $\mathrm{KCl}$ vs. mixed muscarinic stimulation

$\mathrm{KCl}, 50 \mathrm{mM}$

$2.86 \pm 0.22$

$2.46 \pm 0.12$

$n=8$

Carbachol, $1 \mu \mathrm{M}$

$0.95 \pm 0.15$

$1.08 \pm 0.10$

$n=6$

Passive

BZI, $100 \mathrm{nM}$

$2.60 \pm 0.13$

$2.14 \pm 0.22$

$n=6$

Carbachol, $1 \mu \mathrm{M}$

Carbachol, $1 \mu \mathrm{M}+$ THRX-182087, $100 \mathrm{nM}$

$2.90 \pm 0.21$

$2.33 \pm 0.12 *$

$n=6$

Carbachol, $1 \mu \mathrm{M}+$ THRX-182087, $100 \mathrm{nM}$

Series 5: $\mathrm{M}_{3}$ stimulation in absence and presence of protein kinase $\mathrm{C}$ inhibitor

Carbachol, $1 \mu \mathrm{M}+$ THRX-182087, $100 \mathrm{nM}$

$2.89 \pm 0.51$

$2.90 \pm 0.22$

$n=6$

$n=6$ 
did not differ significantly between the two conditions (Fig. 2).

The second series of experiments explored whether selective $M_{2}$ receptor stimulation mimics the effect of carbachol. Based upon previous data that BZI alone causes little bladder contraction (Schneider et al. 2005), we compared BZI with passive tension and confirmed the lack of effect of BZI on detrusor tone (Table 2). While BZI did not affect maximum isoprenaline-induced relaxation, it significantly reduced its potency (Fig. 3).

The third series addressed the reverse question, i.e., whether selective $\mathrm{M}_{3}$ receptor stimulation (carbachol in presence of THRX-182087) mimics the carbachol effect. Both conditions caused comparable starting tension (Table 2).
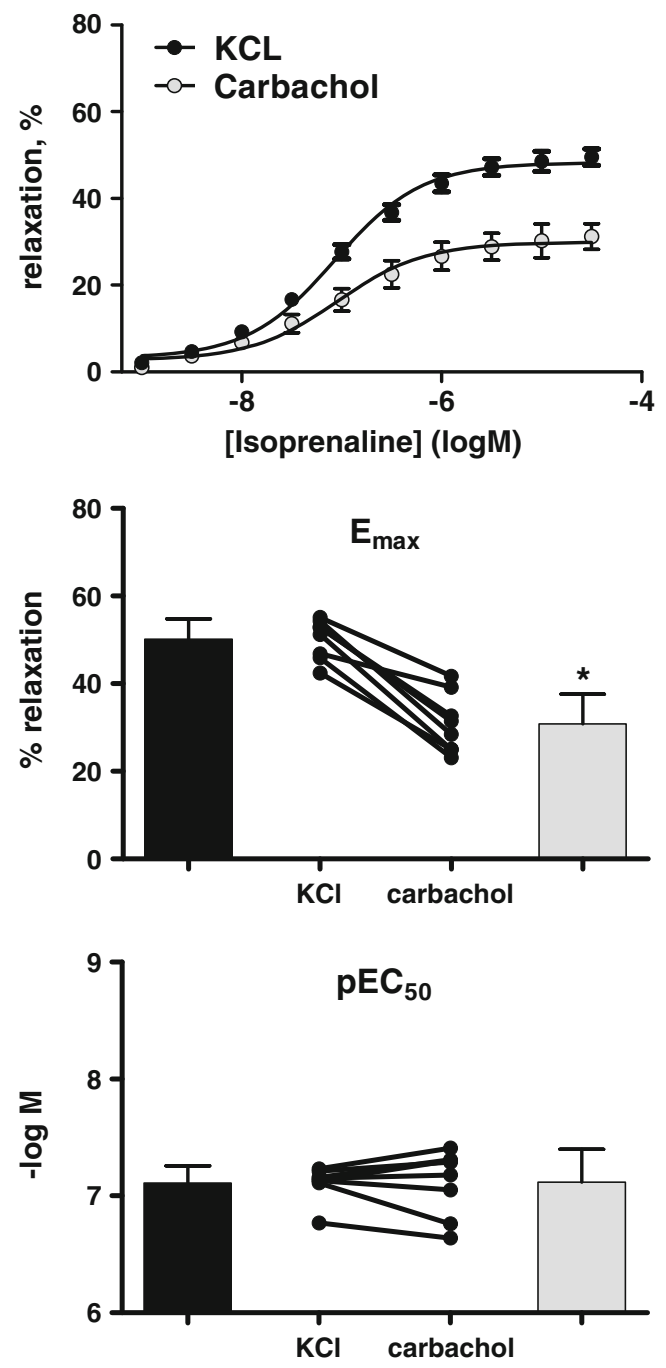

Fig. 2 Comparison of isoprenaline-induced relaxation against tension induced by $50 \mathrm{mM} \mathrm{KCl}$ and $1 \mu \mathrm{M}$ carbachol. Upper panel data are means $\pm \operatorname{SEM}(n=6)$. Middle and lower panel bars showing $E_{\max }$ and $\mathrm{pEC}_{50}$ as derived from the curves in the upper panel indicate means $\pm \mathrm{SEM}$, whereas filled circles represent individual experiments. ${ }^{*} p<0.05$ vs. $\mathrm{KCl}$ in a paired $t$ test
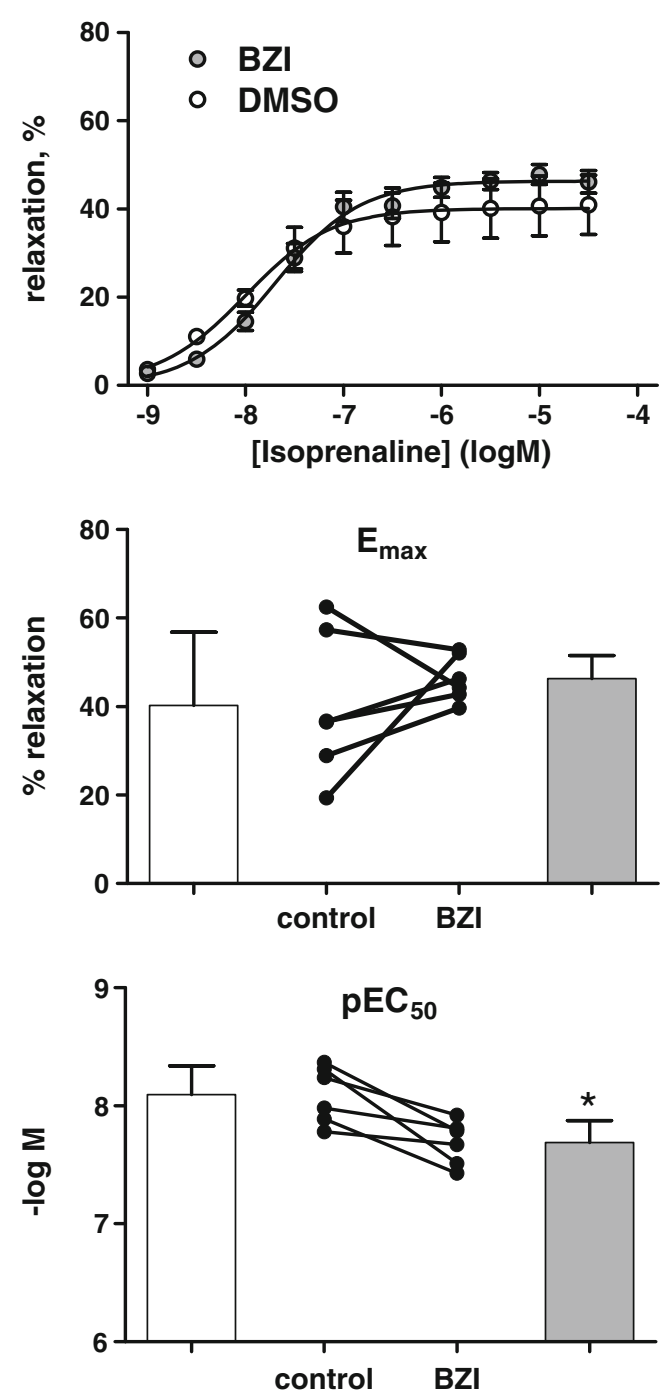

Fig. 3 Comparison of passive tension and $\mathrm{M}_{2}$-selective muscarinic stimulation by $100 \mathrm{nM} \mathrm{BZI}$ on isoprenaline-induced relaxation. Upper panel data are means \pm SEM $(n=6)$. Middle and lower panel bars showing $E_{\max }$ and $\mathrm{pEC}_{50}$ as derived from the curves in the upper panel indicate means $\pm \mathrm{SEM}$, whereas filled circles represent individual experiments. ${ }^{*} p<0.05$ vs. passive tension in a paired $t$ test

The potency and efficacy of isoprenaline were significantly greater upon $\mathrm{M}_{3}$ selective as compared to general muscarinic receptor stimulation, confirming a contribution of $\mathrm{M}_{2}$ receptors to the attenuation of the isoprenaline response (Fig. 4). However, the enhancement of isoprenaline responses by $\mathrm{M}_{2}$ blockade (Fig. 4) was quantitatively less than the attenuation by carbachol (Fig. 2), indicating that both subtypes contribute to the attenuation of isoprenaline responses by carbachol.

The fourth and fifth series of experiments explored whether PLC and/or PKC contribute to the attenuation of isoprenaline responses by $\mathrm{M}_{3}$-selective stimulation. In the presence of the PLC inhibitor U 73,122 starting tension was significantly smaller than with $\mathrm{M}_{3}$-selective stimulation 

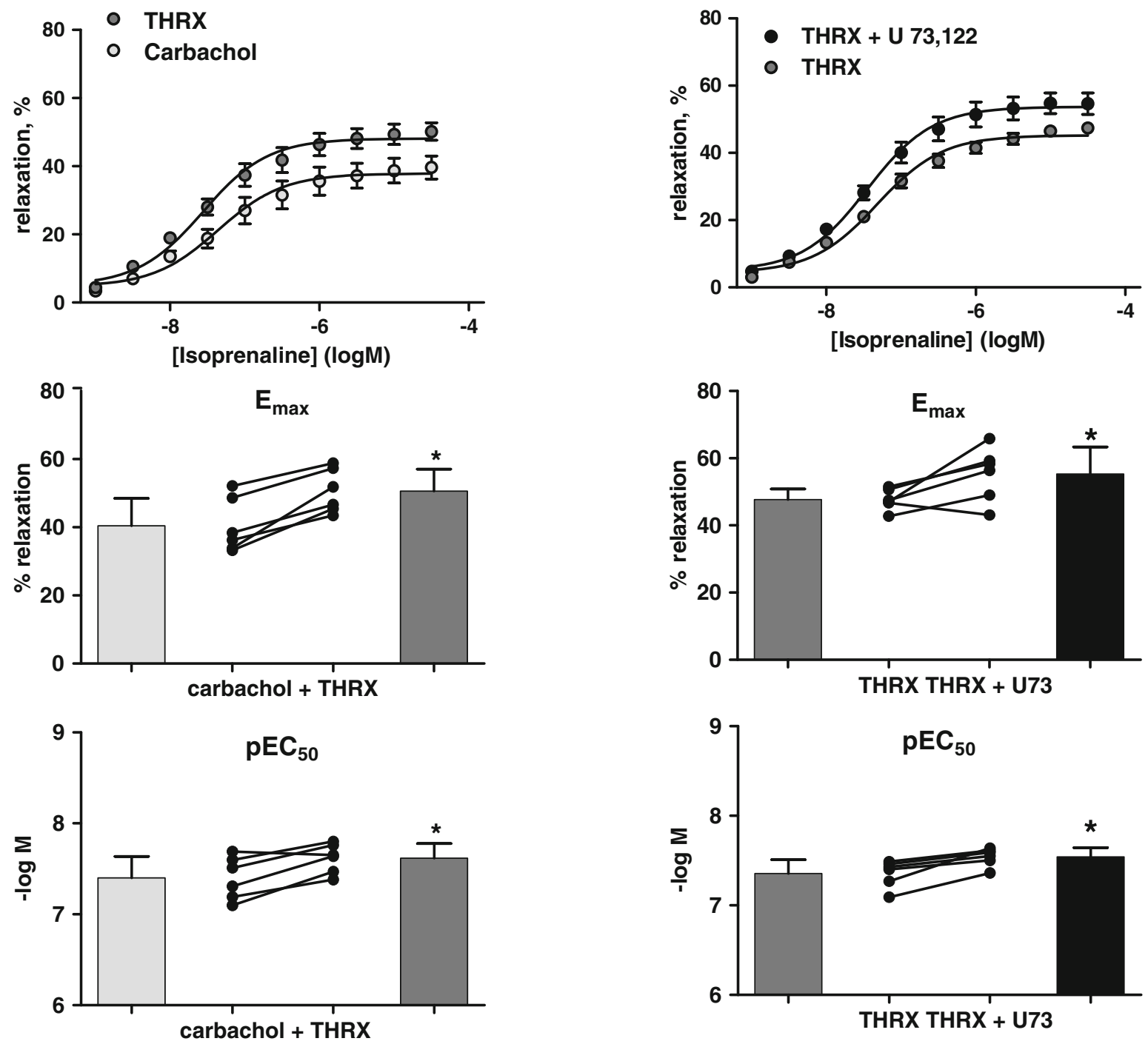

Fig. 4 Comparison of mixed $(1 \mu \mathrm{M}$ carbachol $)$ vs. $\mathrm{M}_{3}$-selective muscarinic stimulation $(1 \mu \mathrm{M}$ carbachol $+100 \mathrm{nM}$ THRX-182087) on isoprenaline-induced relaxation. Upper panel data are means \pm SEM $(n=6)$. Middle and lower panel bars showing $E_{\max }$ and $\mathrm{pEC}_{50}$ as derived from the curves in the upper panel indicate means $\pm \mathrm{SEM}$, whereas filled circles represent individual experiments. ${ }^{*} p<0.05$ vs. carbachol alone in a paired $t$ test

alone (Table 2). Potency and efficacy of isoprenaline were significantly greater in the presence of U 73,122 (Fig. 5). In contrast, the PKC inhibitor chelerythrine affected neither starting tension (Table 2) nor potency or efficacy of isoprenaline-induced relaxation (Fig. 6).

\section{Discussion}

Our study introduces a novel highly $\mathrm{M}_{2}$-selective antagonist (THRX-182087) and uses it together with the $\mathrm{M}_{3}$ sparing agonist BZI to explore the muscarinic receptor subtypes involved in the attenuation of isoprenaline effects

in rat urinary bladder as well as the signalling pathways mediating such attenuation. According to our competition binding data, THRX-182087 is 281-fold selective for $\mathrm{M}_{2}$ over $\mathrm{M}_{3}$ receptors. Selectivity over other muscarinic receptors is $50-4,000$-fold. This compares favorably to the limited $\mathrm{M}_{2}$ selectivity of other compounds which have been used in this field such as methoctramine which is only 30fold selective (Hegde et al. 1997). While the selectivity of THRX-182087 over $\mathrm{M}_{4}$ receptors is less pronounced, these receptors are of little importance in the regulation of bladder smooth muscle tone (Hegde 2006). Hence, for practical purposes, THRX-182087 is a highly selective $\mathrm{M}_{2}$ antagonist in our experimental setting. The THRX-182087 

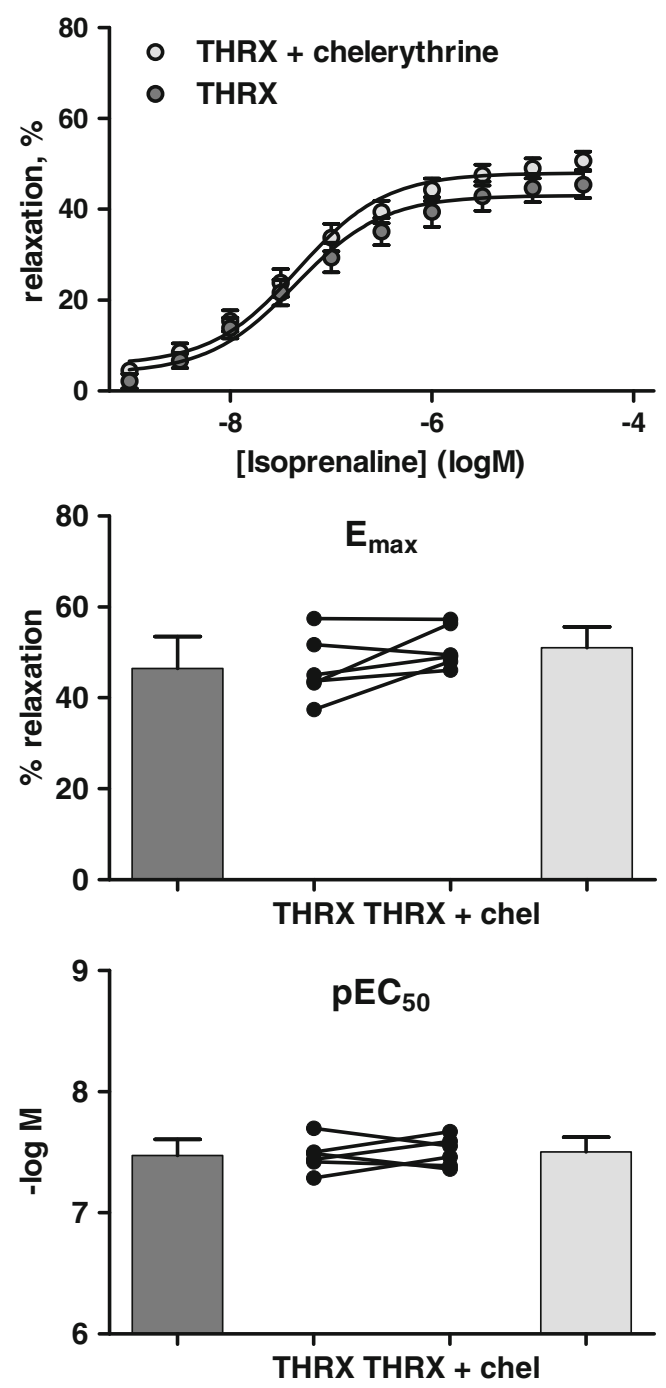

Fig. 6 Effect of the the protein kinase $\mathrm{C}$ inhibitor chelerythrine $(1 \mu \mathrm{M})$ on isoprenaline-induced relaxation during $\mathrm{M}_{3}$-selective stimulation $(1 \mu \mathrm{M}$ carbachol $+100 \mathrm{nM}$ THRX-182087). Upper panel data are means \pm SEM $(n=6)$. Middle and lower panel bars showing $E_{\max }$ and $\mathrm{pEC}_{50}$ as derived from the curves in the upper panel indicate means $\pm \mathrm{SEM}$, whereas filled circles represent individual experiments. Data in the absence and presence of the signalling inhibitor were not significantly different in a paired $t$ test $(p>0.05)$

concentration of $100 \mathrm{nM}$ used in our studies produces an almost complete occupancy of $\mathrm{M}_{2}$ receptors, and accordingly the combination of carbachol with THRX-182087 provides selective $\mathrm{M}_{3}$ agonism.

BZI has been introduced as an $\mathrm{M}_{3}$-sparing agonist (Jasper et al. 2002; Yamakawa et al. 2001a), and our binding data show a more than 3,000-fold selectivity for $\mathrm{M}_{2}$ over $\mathrm{M}_{3}$ receptors. Selectivity over other muscarinic receptors is 3-390-fold. Accordingly, BZI provides selective stimulation of $\mathrm{M}_{2}$ receptors in bladder smooth muscle, where only $\mathrm{M}_{2}$ and $\mathrm{M}_{3}$ receptors are functionally relevant (Hegde 2006). The combined use of THRX-182087 and
BZI has enabled us to explore the relative roles of $\mathrm{M}_{2}$ and $\mathrm{M}_{3}$ receptors in the attenuation of isoprenaline-induced relaxation.

Our data on starting tension demonstrate that inhibition of the $\mathrm{M}_{2}$ receptors did not attenuate carbachol responses, whereas selective activation of $\mathrm{M}_{2}$ receptors did not induce contraction as also observed in previous studies (Schneider et al. 2005). These data confirm a large body of evidence that despite the much larger presence of $\mathrm{M}_{2}$ receptors in the urinary bladder, direct contractile responses are mediated predominantly if not exclusively by the $\mathrm{M}_{3}$ receptor (Hegde 2006).

Studies in multiple tissues and species had demonstrated that muscarinic receptors can attenuate relaxation responses to the $\beta$-adrenoceptor agonist isoprenaline (see "Introduction" section), and this is confirmed in the present data. While such attenuation was found very consistently, those previous studies had been inconsistent with regard to the question whether such attenuation affects the potency and/or efficacy of isoprenaline, and our data also are not fully consistent in this regard.

Studies based on knockout mice had indicated that the $\mathrm{M}_{2}$ subtype, which contributes little to direct detrusor contraction, plays a role in the attenuation of the relaxation response (Ehlert et al. 2005; Matsui et al. 2003; Pak et al. 2010). Using the complementary approach of selective pharmacological stimulation by BZI, we confirm a role of $\mathrm{M}_{2}$ receptors in the attenuation of relaxation. Our finding that selective inhibition of $\mathrm{M}_{2}$ receptors by THRX-182087 in the presence of carbachol enhances relaxation by isoprenaline further corroborates this idea. However, it should be noted that neither the effect of BZI nor that of THRX-182087 can fully explain the attenuation obtained by mixed muscarinic stimulation using carbachol alone, suggesting that the attenuation response may also contain an $\mathrm{M}_{3}$ component.

Stimulation of the PLC/PKC pathway is a prototypical signalling response of $\mathrm{M}_{3}$ receptors (Caulfield and Birdsall 1998; Ehlert et al. 1997) which also was detected in the bladder as being mediated predominantly if not exclusively via $\mathrm{M}_{3}$ receptors (Kories et al. 2003; Nelson et al. 2004). Nevertheless, $\mathrm{M}_{3}$ receptor-mediated bladder contraction has been shown to be insensitive to inhibition of PLC or PKC in rats, mice, and humans (Frazier et al. 2008). In the present study, we have used the PLC inhibitor U 73,122 in a concentration where it fully suppresses inositol phosphate formation in the bladder but does not affect rat or human bladder contraction (Schneider et al. 2004a, b). Interestingly, U 73,122 significantly enhanced isoprenaline-induced relaxation in the presence of $\mathrm{M}_{3}$-selective stimulation. Thus, PLC may be involved in the $\mathrm{M}_{3}$ component of attenuation of relaxation but not in direct bladder contraction mediated by the same receptor subtype. According to our data, PKC is 
not involved in either response, indicating that the involvement of PLC in the attenuation of relaxation occurs via a PKC-independent pathway.

In conclusion, we have introduced a novel antagonist with very high selectivity for $\mathrm{M}_{2}$ over $\mathrm{M}_{3}$ receptors, THRX-182087. Using this compound as well as the $\mathrm{M}_{3}$ sparing agonist BZI, we confirm a role for $\mathrm{M}_{2}$ receptors in the attenuation of isoprenaline-induced bladder relaxation, which previously was mainly supported by genetic evidence, by a pharmacological approach. Our data also suggest involvement of $\mathrm{M}_{3}$ receptors in this attenuation. Thus, muscarinic receptors cause direct contraction and inhibition of relaxation in the bladder, but the two responses involve different subtypes and, at least for $\mathrm{M}_{3}$ receptors, different signalling pathways. This interaction may become clinically relevant under pathophysiological conditions when acetylcholine is being released in the bladder during the storage phase of the micturition cycle.

Acknowledgments This work was supported in part through Coordination Theme 1 (Health) of the European Community's FP7, Grant agreement number HEALTH-F2-2008-223234.

Open Access This article is distributed under the terms of the Creative Commons Attribution Noncommercial License which permits any noncommercial use, distribution, and reproduction in any medium, provided the original author(s) and source are credited.

\section{References}

Andersson K-E (2011) Antimuscarinic mechanisms and the overactive detrusor: an update. Eur Urol 59:377-386

Andersson K-E, Chapple CR, Cardozo L, Cruz F, Hashim H, Michel MC, Tannenbaum C, Wein AJ (2009) Pharmacological treatment of overactive bladder: report from the International Consultation on Incontinence. Curr Opin Urol 19:380-397

Braverman AS, Ruggieri MR (1999) Selective alkylation of rat urinary bladder muscarinic receptors with 4-DAMP mustard reveals a contractile function for the $\mathrm{M}_{2}$ muscarinic receptor. $\mathrm{J}$ Recept Signal Transduct Res 19:819-833

Caulfield MP, Birdsall NJ (1998) International Union of Pharmacology. XVII. Classification of muscarinic acetylcholine receptors. Pharmacol Rev 50:279-290

Cheng Y-C, Prusoff WH (1973) Relationship between the inhibition constant $\left(\mathrm{K}_{\mathrm{i}}\right)$ and the concentration of inhibitor which causes $50 \%$ inhibition $\left(\mathrm{I}_{50}\right)$ of an enzymatic reaction. Biochem Pharmacol 22:3099-3108

Ehlert FJ (2003) Pharmacological analysis of the contractile role of $\mathrm{M}_{2}$ and $\mathrm{M}_{3}$ muscarinic receptors in smooth muscle. Receptors Channels 9:261-277

Ehlert FJ, Ostrom RS, Sawyer GW (1997) Subtypes of the muscarinic receptor in smooth muscle. Life Sci 61:1729-1740

Ehlert FJ, Griffin MT, Abe DM, Vo TH, Taketo MM, Manabe T, Matsui M (2005) The M2 muscarinic receptor mediates contraction through indirect mechanisms in mouse urinary bladder. J Pharmacol Exp Ther 313:368-378

Ehlert FJ, Ahn S, Pak KJ, Park GJ, Sangnil MS, Tran JA, Matsui M (2007) Neuronally released acetylcholine acts on the M2 muscarinic receptor to oppose the relaxant effect of isoproterenol on cholinergic contractions in mouse urinary bladder. J Pharmacol Exp Ther 322:631-637

Frazier EP, Peters SL, Braverman AS, Ruggieri MR Sr, Michel MC (2008) Signal transduction underlying the control of urinary bladder smooth muscle tone by muscarinic receptors and betaadrenoceptors. Naunyn Schmiedebergs Arch Pharmacol 377:449-462

Frazier EP, Michel-Reher MB, van Loenen P, Sand C, Schneider T, Peters SLM, Michel MC (2011) Lack of evidence that nebivolol is a $\beta_{3}$-adrenoceptor agonist. Eur J Pharmacol 654:86-91

Griffin MT, Matsui M, Ostrom RS, Ehlert FJ (2009) The guinea pig ileum lacks the direct, high-potency, $\mathrm{M}_{2}$ muscarinic, contractile mechanism characteristic of the mouse. Naunyn Schmiedebergs Arch Pharmacol 380:327-335

Hegde SS (2006) Muscarinic receptors in the bladder: from basic research to therapeutics. Br J Pharmacol 147(Suppl 2):S80-S87

Hegde SS, Choppin A, Bonhaus D, Briaud S, Loeb M, Moy TM, Loury D, Eglen RM (1997) Functional role of M2 and M3 muscarinic receptors in the urinary bladder of rats in vitro and in vivo. Br J Pharmacol 120:1409-1418

Jasper JR, Pulido-Rios MT, Stangeland E, Griffin JH, Horger B, Beattie D, Li G, Lee TW, Steinfeld T, Mammen M, Hegde SS (2002) Pharmacological characterization of a modified benzimidazolidnone, a potent muscarinic receptor agonist displaying selectivity for $\mathrm{M}_{2}$ and $\mathrm{M}_{4}$ receptor subtypes. Pharmacologist 44 (Suppl 1):110.6

Kories C, Czyborra C, Fetscher C, Schneider T, Krege S, Michel MC (2003) Gender comparison of muscarinic receptor expression and function in rat and human urinary bladder: differential regulation of M2 and M3 receptors? Naunyn Schmiedebergs Arch Pharmacol 367:524-531

Longhurst PA, Levendusky M (1999) Pharmacological characterization of beta-adrenoceptors mediating relaxation of the rat urinary bladder in vitro. Br J Pharmacol 127:1744-1750

Matsui M, Motomura D, Fujikawa T, Jiang J, Si T, Manabe T, TAketo MM (2002) Mice lacking $M_{2}$ and $M_{3}$ muscarinic acetylcholine receptors are devoid of cholinergic smooth muscle contractions but still viable. J Neurosci 22:10627-10632

Matsui M, Griffin MT, Shehnaz D, Taketo MM, Ehlert FJ (2003) Increased relaxant action of forskolin and isoproterenol against muscarinic agonist-induced contractions in smooth muscle from M2 receptor knockout mice. J Pharmacol Exp Ther 305:106-113

Michel MC, Parra S (2008) Similarities and differences in the autonomic control of airway and urinary bladder smooth muscle. Naunyn Schmiedebergs Arch Pharmacol 378:217-224

Michel MC, Sand C (2009) Effect of pre-contraction on betaadrenoceptor-mediated relaxation of rat urinary bladder. World $\mathrm{J}$ Urol 27(6):711-715

Michel MC, Vrydag W (2006) Alpha1-, alpha2- and beta-adrenoceptors in the urinary bladder, urethra and prostate. Br J Pharmacol 147 (Suppl 2):S88-S119

Naline E, Trifilieff A, Fairhurst RA, Advenier C, Molimard M (2007) Effect of indacaterol, a novel long-acting beta2-agonist, on isolated human bronchi. Eur Respir J 29:575-581

Nelson CP, Gupta P, Napier CM, Nahorski SR, Challiss RA (2004) Functional selectivity of muscarinic receptor antagonists for inhibition of M3-mediated phosphoinositide responses in guinea pig urinary bladder and submandibular salivary gland. J Pharmacol Exp Ther 310:1255-1265

Offermanns S, Wieland T, Homann D, Sandmann J, Bombien E, Spicher K, Schultz G, Jakobs KH (1994) Transfected muscarinic acetylcholine receptors selectively couple to Gi-type G proteins and Gq/11. Mol Pharmacol 45:890-898

Ostrom RS, Ehlert FJ (1998) M2 muscarinic receptors inhibit forskolin- but not isoproterenol-mediated relaxation in bovine tracheal smooth muscle. J Pharmacol Exp Ther 286:234-242 
Ostrom RS, Ehlert FJ (1999) Comparison of functional antagonism between isoproterenol and M2 muscarinic receptors in guinea pig ileum and trachea. J Pharmacol Exp Ther 288:969-976

Pak KJ, Ostrom RS, Matsui M, Ehlert FJ (2010) Impaired M3 and enhanced M2 muscarinic receptor contractile function in a streptozotocin model of mouse diabetic urinary bladder. Naunyn Schmiedebergs Arch Pharmacol 381:441-454

Roffel AF, Meurs H, Elzinga CRS, Zaagsma J (1995) No evidence for a role of muscarinic $\mathrm{M}_{2}$ receptors in functional antagonism in bovine trachea. Br J Pharmacol 115:665-671

Sarria B, Naline E, Zhang Y, Cortijo J, Molimard M, Moreau J, Therond P, Advenier C, Morcillo EJ (2002) Muscarinic M2 receptors in acetylcholine-isoproterenol functional antagonism in human isolated bronchus. Am J Physiol Lung Cell Mol Physiol 283:L1125-L1132

Schneider T, Fetscher C, Krege S, Michel MC (2004a) Signal transduction underlying carbachol-induced contraction of human urinary bladder. J Pharmacol Exp Ther 309:1148-1153

Schneider T, Hein P, Michel MC (2004b) Signal transduction underlying carbachol-induced contraction of rat urinary bladder. I. Phospholipases and $\mathrm{Ca}^{2+}$ sources. J Pharmacol Exp Ther 308:47-53
Schneider T, Hein P, Michel-Reher MB, Michel MC (2005) Effects of ageing on muscarinic receptor subtypes and function in rat urinary bladder. Naunyn Schmiedebergs Arch Pharmacol 372:71-78

Vrydag W, Michel MC (2009) Agonist-induced desensitization of the $\beta$ adrenoceptors in the rat urinary bladder. Naunyn Schmiedebergs Arch Pharmacol 380:271-272

Yamakawa T, Ando M, Koito S, Ohwaki K, Kimura T, Saeki T, Miyaji M, Iwahori Y, Fujikawa T, Otake N, Noguchi K (2001a) Substituted imidazolidinone derivates. WO2000JP07133 20001013

Yamakawa T, Ando M, Koito S, Ohwaki K, Kimura T, Saeki T, Miyaji M, Iwahori Y, Fujikawa T, Otake N, Noguchi K (2001b) Substituted imidazolidinone derivatives. WO2000JP07133 20001013

Yamanishi T, Chapple CR, Yasuda K, Chess-Williams R (2002) The role of M2 muscarinic receptor subtypes in mediating contraction of the pig bladder base after cyclic adenosine monophosphate elevation and/or selective M3 inactivation. J Urol 167:397-401 